Developing visual art competence in young students (7-9 years old). A comparative study involving students from Romania, Poland, Turkey and the Republic of Moldavia, participants in the eTwinning Programme Gabriela Ileana Crișan, Ion Albulescu 


\title{
Developing visual art competence in young students (7-9 years old). A comparative study involving students from Romania, Poland, Turkey and the Republic of Moldavia, participants in the eTwinning Programme
}

\author{
Gabriela Ileana Crișan ${ }^{a^{*}}$, Ion Albulescu ${ }^{\mathrm{b}}$ \\ ${ }^{a}$ Doctoral School "Educational, Reflection, Development", Babeş-Bolyai University, 7 Sindicatelor Street, 400029, Cluj-Napoca, Romania \\ ${ }^{b}$ Faculty of Psychology and Educational Sciences, Babeş-Bolyai University, 7 Sindicatelor Street, 400015, Cluj-Napoca, Romania \\ *Corresponding author: crisangabriela@gmail.com
}

Abstract

Keywords:

flipped classroom, visual arts, eTwinning
The aim of our study is to highlight the potential of using the blended-learning, flipped classroom, learning strategies in developing the students' competences in the subject of Visual Arts and Practical Abilities within the framework of European school partnerships. The practical and process-oriented research will investigate and describe the gains of flipped classroom strategy in improving the artistic-plastic performances of young students aged 7-9 years, participants in the eTwinning Programme. By means of comparative analyses, we will bring out the effects of applying this strategy to students from Romania, Poland, Turkey and the Republic of Moldavia with regard to forming and developing their visual art competences. We framed these specific competences present in the 4 European countries'curriculum into the plastic theme category, with the subcategories of observing the artistic movement, selected technique, type of chosen tools and materials, lines diversity and expressivity, diversity and complexity of shapes, chromatic harmony, colour surface, ornamentation of composition.
Schlüsselworte: FORCE- Programm, Lebensqualität, ältere Menschen, Psychoedukation
In diesem Studium möchten wir auf das Potenzial der neun Bildungsstrategie, sowie Blended-Learning, flipped classroom hinweisen und wie es auf die Kompetenzbildung der Schüler im Schulfach visuelle Kunst und praktische Fähigkeiten, im Kontext der europäischen Schulpartnerschaft, wirkt. Die praktische Forschung rescherschiert und beschreibt die Wertigkeit der Flipped-Classrooom Strategie, um die künstlerischen Leistugen der Schüler im Alter zwischen 7-9, die Teilnehmer der eTwinning sind, zu verbessern. Wir werden durch eine vergleichende Analyse darauf hinweisen, wie effektiv diese Strategie in Rumänien, in der Republik Moldau, Polen und in der Türkei ist, was die Bildung und die Entwicklung der küntslerischen Kompetenzen betrifft. Wir haben diese spezifischen Kompetenzen von den Schullehrplänen dieser 4 europäischen Ländern in der Kategorie Kunst zusammengesetzt, aber wir haben auch in Acht die künstlerische Richtung, die Technik, die Instrumenten und die ausgewählten Materialen, die Vielfalt und Expresivität der Linien, die Vielfalt und Komplexität der Formen, die kromatische Harmonie, die Farbenoberfläche, Dekoration der Komposition genommen.

\section{Introduction}

As a result of the informational boom generated by the development of technology, schools must permanently adapt and revise their educational offer. Therefore, questions like: What does the student need to know at the time of graduation? What competences should the model employee hold to perfectly fit in the work place ? How could the young generation achieve success in all walks of life?

Due to these continuous transformations, school needs strategies which enables it to balance the society trends and the children's education in view of their integration in society. Flipped classroom can be addressed not only to diminish the gaps generated by class absenteeism caused by different reasons, but also to reduce the differences related to students' reaction speed during the lessons. Since art plays an important part in establishing the balance between man and society (Vygotsky, 1973), we therefore consider the choice of international eTwinning cooperation projects as appropriate and as a framework in which flipped classroom learning strategy may be used with the purpose of forming the students' visual art competences.

In the present work, we aim at analyzing the visual art competences of 7-9 years old students from Romania, the Republic of Moldavia, Poland and Turkey participants in the ARTmania eTwinnig projects with a view to identify 
the way in which the application of flipped classroom learning strategy contributes to the development of such competences. We have opted for this approach for several reasons:

1) Flipped classroom strategy is gaining more and more popularity in learning activities, with positive results in Europe and worldwide;

2) eTwinning cooperation projects contribute to the rapid spreading of ideas and experiences among countries inside and outside Europe.

The research objectives:

a) The comparative analysis of the curriculum of visual art subjects in Romania, the Republic of Moldavia, Poland and Turkey with respect to create some flipped classroom -tailored tutorials

b) The analysis of developing specific visual artoriented competences in the students belonging to the four European countries, participants in the ARTmania eTwinning projects.

\section{Theoretical background}

According to school curricula, specific competences are defined as acquisitions that are meant to be reached at the end of a school year for each subject. However, specific competences are differently defined in the curricula of each participant country in the ARTmania eTwinning projects.

In Romania, specific competences derive from general competences and developed by means of Learning Activities (the learning activities occur only as suggestions in the curriculum, the teacher being free to organize learning experiences by selecting the relevant activities). Due to the fact that Visual Arts And Practical Abilities is already an integrated subject, created by the juxtaposition of Arts and Technology, in this study we took into account the specific competences for the visual art field. We used the curriculum for VISUAL ARTS AND PRACTICAL ABILITIES as a landmark which represents Annex 2 to the Order of the National Education Ministry no. 3418/ 19.03.2013 (for grades I and II), respectively no. 5003/ 02.12.2014 (for grades III).

In Moldavia, specific competences are set out in the curriculum as acquisitions gained at the end of the educational stage, with sub-competences corresponding to the acquisitions gained at the end of the school year. The curriculum for Visual Art Education is comprised in the School Curriculum for grades I-IV approved of in the National Council for the Curriculum meeting on 30.04.2010 by Order of Ministry of Education no. 331 of 12.05.2010.

In Poland, acquisitions gained at the end of the school year are defined in terms of abilities, knowledge and competences. The curriculum mentioned by our partners and consulted in the eTwinning projects is Gra w Kolory, Program Nauczania Edukacji Wczesnoszkolnej issued in the year 2009 by Juka Publishing House in Warsaw under the signature of Ewa Stolarczyk.

In Turkey, the learning areas are detailed for each school year in terms of knowledge, abilities and competences. Examples of learning abilities are offered to encourage the acquisition of competences according to the curriculum for Aesthetic Education, ILLKOKUL've Ortaokul Görsel Sanatlar Dersi Öğretim Programı, in force since the year 2013 .

In the table below, we carried out comparative analyses of the curricula for Visual Arts/Plastic Education in Romania, the Republic of Moldavia, Poland and Turkey. The motivation for such a comparison is given, on the one hand, by developing an educational programme based on using art movements in order to meet the needs of developing visual art competences in primary school children (7-9 years old). On the other hand, schools from these countries have started ARTmania eTwinning projects, and their integration into the curriculum requires the setting of common goals and objectives based on similar contents and competences.

Table no. 1. Comparative analysis of competences specific to Visual Arts and Practical Abilities/Visual Art Education within primary education in Romania, Republic of Moldavia, Turkey and Poland

\begin{tabular}{|c|c|c|c|c|}
\hline $\begin{array}{c}\text { Items of common } \\
\text { competences }\end{array}$ & Romania & $\begin{array}{c}\text { The Republic of } \\
\text { Moldavia }\end{array}$ & Poland & Turkey \\
\hline & $\begin{array}{c}\text { 1. Noticing the } \\
\text { difference between the }\end{array}$ & $\begin{array}{c}\text { To create works on the } \\
\text { same topic in materials }\end{array}$ & $\begin{array}{c}\text { Expresses own } \\
\text { experience in a variety }\end{array}$ & $\begin{array}{c}\text { Identifying the differences } \\
\text { between the subject of an }\end{array}$ \\
\hline
\end{tabular}




\begin{tabular}{|c|c|c|c|c|}
\hline \multirow{2}{*}{$\begin{array}{l}\text { Competences in } \\
\text { communication } \\
\text { and visual art } \\
\text { appreciation }\end{array}$} & $\begin{array}{c}\text { practical information } \\
\text { sent through visual } \\
\text { language and artistic } \\
\text { message; }\end{array}$ & $\begin{array}{l}\text { of classical art as well } \\
\text { as modern materials; }\end{array}$ & $\begin{array}{l}\text { of artistic techniques } \\
\text { on a flat plane and in } \\
\text { space; }\end{array}$ & art work; \\
\hline & $\begin{array}{l}\text { 2. Identification of } \\
\text { meaning in the line, } \\
\text { the dot, the colour and } \\
\text { the shape of a work of } \\
\text { art; }\end{array}$ & $\begin{array}{l}\text { To notice the } \\
\text { peculiarities of lines, } \\
\text { dots, colours, shapes } \\
\text { used in the nature and } \\
\text { in a diversity of artistic } \\
\text { contexts; }\end{array}$ & $\begin{array}{l}\text { Recognizes the } \\
\text { selected art work } \\
\text { belonging to European } \\
\text { and Polish cultural } \\
\text { patrimony; }\end{array}$ & $\begin{array}{l}\text { Noticing the formal } \\
\text { properties of a work of } \\
\text { art: colour, line, shape; }\end{array}$ \\
\hline \multirow{3}{*}{$\begin{array}{l}\text { Competences in } \\
\text { using visual art } \\
\text { means }\end{array}$} & $\begin{array}{l}\text { 3.Exploration of some } \\
\text { characteristics/ } \\
\text { properties of materials } \\
\text { in different contexts; }\end{array}$ & $\begin{array}{l}\text { To obtain dots, lines, } \\
\text { stains, shapes, colours } \\
\text { using a diversity of } \\
\text { materials and artistic } \\
\text { means; }\end{array}$ & $\begin{array}{l}\text { Describes their } \\
\text { characteristics, using } \\
\text { basic terminology for } \\
\text { this creative field of } \\
\text { activity; }\end{array}$ & $\begin{array}{c}\text { Analysis of examples of } \\
\text { figurative art: principles, } \\
\text { materials, techniques, } \\
\text { colours, lines, message, } \\
\text { balance, value. }\end{array}$ \\
\hline & $\begin{array}{l}\text { 4. Expressing personal } \\
\text { ideas and feelings by } \\
\text { means of the line, dot, } \\
\text { colour and shape; }\end{array}$ & $\begin{array}{c}\text { To render certain state } \\
\text { of nature by use of } \\
\text { colours and non - } \\
\text { colours; }\end{array}$ & $\begin{array}{l}\text { Achieves artistic } \\
\text { compositions based on } \\
\text { own experiences, } \\
\text { literary or musical; }\end{array}$ & $\begin{array}{c}\text { Analysis of examples of } \\
\text { figurative art: principles, } \\
\text { materials, techniques, } \\
\text { colours, lines, message, } \\
\text { balance, value. }\end{array}$ \\
\hline & $\begin{array}{l}\text { 5. The transformation } \\
\text { of a material through } \\
\text { simple/varied } \\
\text { techniques; }\end{array}$ & $\begin{array}{l}\text { To combine colours in } \\
\text { order to obtain artistic } \\
\quad \text { expressivity; }\end{array}$ & $\begin{array}{l}\text { Creates colour } \\
\text { combinations. }\end{array}$ & $\begin{array}{l}\text { Noticing the formal } \\
\text { properties of a work of } \\
\text { art: colour, line, shape; }\end{array}$ \\
\hline
\end{tabular}

We have compiled the specific competences in the curricula of the four participant countries in the ARTmania eTwinning projects regarding the plastic theme into common competence categories, as follows:

a. Competences in communication and visual art
appreciation

b. Competences in using visual art means.

The plastic theme criterion taken into account in the present study is one of the components of the research tool (criterion evaluation grid) and comprises eight subcriterion referring to observing the artistic movement, the chosen technique, type of selected instruments and materials, expressivity and diversity of lines, diversity and complexity of shapes, chromatic harmony, colour surface, ornamentation of composition. Each subcriterion is closely connected to one or more specific competences.

The composition of each sub-criterion is presented below:

Sub-criterion 1. The compliance with the artistic movement comprises both the consideration of the peculiarities of the artistic movement of Impressionism, Cubism and abstract Expressionism. Therefore, we monitored the presence in the students' impressionist art works of the following aspects: light-shadow alternance, the use of ,coloured commas", the use of cool colors for rendering distance and of warm colours for closeness, the use of bright colours, the delimitation of the land and air plan, the avoidance of using black shades and earth tones. What we observed in the art works achieved in cubist manner were: the use of geometric shapes, of brownish colours, the shapes alignment in unexpected ways, the clear and natural setting of the starting point in shapes. In the expressionist-like works of art, we assessed the representation of feelings through different artistic gestures, fast, spontaneous painting, freedom in choosing the colours, the techniques and tools.

Sub-criterion 2. The selected techniques refers to the artistic techniques provisioned by the curriculum for grades I-III for the subject Visual Arts and Practical Abilities: shading, scaling, repetition, brushing, collage, printing, dabbing, sprinkling.

Sub-criterion 3. The type of chosen tools and materials refers to the recommendations in the curriculum for grades I-III for Visual Arts and Practical Abilities with regard to the use of: water colours, gouaches, tempera, sponges, paint brushes (of different sizes), the finger, stamp, paper/ linen, graphite/ coloured pencils, wax crayons etc. 
Sub-criterion 4.The diversity and expressivity of lines is considering the existence of vertical, horizontal, slant, broken(folded), curved types of lines in the student's art works.

Sub-criterion 5. The diversity and complexity of shapes refers to the occurrence of figurative types: vegetal, animal, human, objectual, cosmic as well as of simple, complex or combined types.

Sub-criterion 6 . The chromatic harmony applies to the presence of contrasts: warm-cool, dark-bright, dominant colour, mixing colours.

Sub-criterion 7. Texture (colour surface) takes into account the presence of different texture types in the students' artworks: flat, smooth, lumpy, tabular or fibrilar.

Sub-criterion 8. The ornamentation of composition implies the composition of the artistic space through different ornamental elements such as: graphic overlapping of line, dots, colours.

Each sub-criterion is detailed by performance descriptors translated into grades of Very Good (FB), Good (B), Sufficient (S) and Insufficient (I) in accordance with the grading system in the Romanian primary education, yet, the grid can be easily adapted to other evaluation systems as well.

\section{Flipped classroom}

Flipped classroom learning strategy is becoming more and more popular in international educational practices. There are a series of studies which confirm the role of this strategy in increasing students' performances in different subjects. Most of them spotlight the increase of students' performances in Maths (Lai \& Hwang, 2016), Informatics (Zhong, Song \& Jiao, 2013), History (Aidinopoulou \& Sampson, 2017), Foreign Languages (Shaffer, 2015). The teachers' opinions regarding the use of flipped chart classroom in primary education vary from optimism to skepticism. In the survey regarding "The contribution of flipped classroom and eTwinning projects to altering teachers' perception on organizing learning experiences in the field of Aesthetic Education" conducted in Romania in 2018 on a sample of 110 experienced teachers in carrying out international cooperation projects, we concluded that the main objections to implementing the flipped classroom in young students arose from the lack of time for preparing the video materials and the necessity to educate the parents in view of understanding the peculiarities of this learning strategy. Flipped classroom comprises an online component (the tutorial) and a faceto-face component, respectively the acquired knowledge application session, with a permanent feedback from the teacher. In ARTmania eTwinning projects, the partners created and shared the tutorials and organized work sessions in which the students worked individually and in groups.

A series of stages were complied with in the process of developing tutorials which included the consultation of curricula for grades I, II and III for the subject Visual Arts and Practical Abilities in partnership with Alin Bîlcu, Arts teacher in selecting the competences and the contents to be taken into account in the video tutorials, in conjunction with the selected competences and contents for painting styles specific to some internationally established artistic movements, in selecting the potential cross-disciplinary artistic movements, adjusting the specific of artistic movements to age peculiarities, the planning of the teaching scenario to be applied to the video material, adjusting the length of tutorials to the peculiarities of brain's abilities to focus on a task, recording the video material, its uploading on the Web (Youtube) and its sharing within the project space (Twinspace), the tutorial subtitling for the foreign partners, obtaining feedback from partners (with the redoing of the material in case of negative feedback).

\section{Method}

The research started from the idea of organizing some relevant learning experiences for primary students in the field of visual arts within the context of ARTmania eTwinning projects.

The selected partners in the projects subject to our research are experienced teachers, mostly novice in the eTwinning. The experimental sample comprised a number of 328 students aged 7-9 years old from Romania, the Republic of Moldavia, Poland and Turkey participant in the ARTmania eTwinning projects conducted within the years 2016-2018. The formative experiment comprised the students' watching the tutorials at home of the impressionist, cubist and abstract expressionist artistic 
styles performed by us, followed by their classroom practice sessions.

The following materials were made available to the 328 students in both the pre-testing, respectively the posttesting and re-testing stages: white sheets of paper, water colours, paint brushes, glass of water, sponges, coloured pencils, wax pencils, graphite. The task was announced: to make a drawing of their choice on "Nature Landscapes" or "Portrait", using their favourite available materials. The two themes represent frequent and favourite topics for young-aged students. The students chose their own working techniques among the previously studied ones. They were told that their works would not be graded and that there would be no wrong drawings. The students were advised to let go of their imagination. All the drawings were individually made during school time, with no support from the teacher. The duration time for the activity was 1 hour, no other directions being given.
The drawings of the students in the experimental sample group were posted on the project's eTwinning space. The drawings were being labeled, mentioning the students' initials and ages.

The students' art works were being analyzed by means of the criterial evaluation grid developed by us. Grades for each sub-criterion were being set up according to the performance descriptors defined in the grid.

The analysis of the results obtained in the pre-testing/ re-testing stages by the experimental sample group.

The analysis of the values achieved by the experimental sample group in the pre-testing stage on the Plastic Theme criterion illustrates a significant increase in the mean of Very Well (FB) grade (Mre-test=170,63 from Mpre-test $=48,00$ ), as well as a decrease in the means of the other grades: Good (B) (Mre-test=82,75 from Mpretest $=103,25)$, Sufficient (S) (Mre-test=72,13from Mpretest $=142,75)$ and Insufficient (I) (Mre-test $=2,50$ from Mpre-test $=34,00$ ).

Table no. 2. Collected data in the Plastic Theme criterion experimental group, pre-testing/re-testing stages

\begin{tabular}{|c|c|c|c|c|c|}
\hline \multicolumn{2}{|r|}{ Plastic Theme } & $\mathrm{N}$ & Mean & $\begin{array}{l}\text { Standard } \\
\text { deviation }\end{array}$ & $\begin{array}{l}\text { Standard } \\
\text { error mean }\end{array}$ \\
\hline \multirow[t]{2}{*}{ Very Good } & Pre-test experimental group & 8 & 48,00 & 34,773 & 12,294 \\
\hline & Re-test experimental group & 8 & 170,63 & 26,992 & 9,543 \\
\hline \multirow[t]{2}{*}{ Good } & Pre-test experimental group & 8 & 103,25 & 21,796 & 7,706 \\
\hline & Re-test experimental group & 8 & 82,75 & 24,070 & 8,510 \\
\hline \multirow[t]{2}{*}{ Sufficient } & Pre-test experimental group & 8 & 142,75 & 28,524 & 10,085 \\
\hline & Re-test experimental group & 8 & 72,13 & 6,221 & 2,199 \\
\hline \multirow[t]{2}{*}{ Insufficient } & Pre-test experimental group & 8 & 34,00 & 18,346 & 6,486 \\
\hline & Re-test experimental group & 8 & 2,50 & 1,927 & ,681 \\
\hline
\end{tabular}

The hypotheses for the $\mathrm{T}$ test were being launched:

The Ho null hypothesis: the mean of differences between the values obtained in the experimental sample group in the pre-testing and re-testing stages is 0.
The H1 research hypothesis: the mean of differences between the values obtained in the experimental sample group in the pre-testing and re-testing stages is other than 0 . 
By assessing the results obtained in the T test, we can notice values of $\mathrm{p}<0,05$ which supports the $\mathrm{H} 1$ hypothesis, which says there are significant differences between the values of the acquired means by the experimental sample group in the pre-testing and retesting stages. An exception is the Good (B) grade $(\mathrm{p}=0,09)$.

Table no. 3. Collected data as a result of applying the t test to the Plastic Theme criterion

\begin{tabular}{|l|r|r|r|r|}
\hline & \multicolumn{2}{|c|}{ Levene Test } & \multicolumn{2}{c|}{ t-Test } \\
\cline { 2 - 5 } & $\begin{array}{c}\text { F (equality } \\
\text { of variances) }\end{array}$ & $\begin{array}{c}\text { Unidirectiona } \\
\text { 1 level of } \\
\text { significance }\end{array}$ & $\mathrm{t}$ & $\begin{array}{c}\text { Bi-dimensional } \\
\text { level of } \\
\text { significance }\end{array}$ \\
\hline Very Good &, 048 &, 830 & $-7,879$ &, 000 \\
\hline Good &, 091 &, 757 & 1,786 &, 096 \\
\hline Sufficient & 7,062 &, 019 & 6,942 &, 000 \\
\hline Insufficient & 18,339 &, 001 & 4,830 &, 000 \\
\hline
\end{tabular}

As a result of the students' re-testing in the experimental sample group, we brought forward the following observations in comparison with the pre-testing stage:

1. The number of Very Good (FB) grades significantly increases, in direct relationship with a decrease in the amount of Insufficient grades; There is a decrease in the number of Sufficient and Good grades;

2. The mean of the values of Good grades does not record significant differences in the two criteria compared to the pre-testing stage.

Table no. 4. Final results in the pre-testing/post-testing/re-testing stages, experimental group.

\begin{tabular}{|l|c|c|c|c|}
\hline \multicolumn{1}{|c|}{ Final results } & Very Good & Good & Sufficient & Insufficient \\
\hline $\begin{array}{l}\text { Pre-testing experimental } \\
\text { group }\end{array}$ & 621 & 1424 & 1856 & 363 \\
\hline $\begin{array}{l}\text { Post-testing experimental } \\
\text { group }\end{array}$ & 1347 & 1425 & 1192 & 300 \\
\hline $\begin{array}{l}\text { Re-testing experimental } \\
\text { group }\end{array}$ & 2284 & 1044 & 915 & 21 \\
\hline
\end{tabular}

By analyzing the acquired data, we notice a gradual increase in the the students' Very Good grades in the experimental group throughout the stages, from pretesting to re-testing. The lowest amount of Very Good grades was recorded in the pre-testing stage (621), with a doubling (1347) at the end of the formative experiment so as to increase to 2284 in the re-testing stage.A similar surprising evolution is obvious in the evolution of Insufficient grades. If their number had a slight fall in the post-testing stage, there is a significant decrease in the retesting stage, to 21 . An identical process is to be noticed in the case of Sufficient grades, their amount being 
reduced to a half in the re-testing stage (915). However, there is a slower drop in the number of Good grades (from 1424 to 1044), they being featured in the Very Good grades.

\section{Conclusions}

In the carrying out of the present research, we started from the finding that contemporary education requires new strategies to attract students' interest towards study. Subjects like Mathematics, Romanian Language and |Literature, English become the target of the parents' and teachers' interest straight from the first school year/grade at the expense of children's emotional development, of educating the aesthetic taste that Arts has. On the other hand, the lack of awareness in the potential of this field in the global development of the children is mainly due to the inability of the Romanian educational system to set up interdisciplinary connections by means of coherent curricula and proper material equipment. Through its general competences, Visual Art education aims at the students' ability to use specific materials and tools, as well as the ability for art reception, of being aware of its aesthetic values. Classical and modern artistic movements constitute paradigms which offer the child the access to these values, also contributing to a paradigmatic thinking. Flipped classroom represents a way of facilitating the achievement of specific competences in the field of visual arts.

The existence of some competence categories and common content elements has been also highlighted, a fact which allowed us to structure our educational programme and its integration into an eTwinning cooperation project. This approach was facilitated by the flexibility of the topics in the school curricula which offer greater freedom to both teachers and students. The students are suggested a wide range of approachable subjects ranging from means and techniques in drawing/painting, from artistic language to elements of arts history, of artistic culture. All these create the premises for developing the student's creativity and for taking into account their abilities. We consider the performing of interdisciplinary connection between visual art education and other subjects such as TIC to be of great importance in view of achieving the students' global development.

\section{Authors note:}

Gabriela Ileana Crisan is Ph.D. student at Doctoral School "Education, Reflection, Development", Faculty of Psychology and Educational Sciences from Babeş-Bolyai University, Cluj-Napoca, Romania.

Ion Albulescu is University habilitated Professor and Ph.D. Coordinator at the Faculty of Psychology and Sciences of Education (Babeş-Bolyai University, ClujNapoca, Romania) Department of Educational Sciences, Faculty of Psychology and Educational Sciences. His research interest is reflected in a series of studies, articles and books published by prestigious international and national editors. The Professor Albulescu teaching and research area covers several educational domains such as Educational Alternatives, Comparative Education, Pedagogical Theories and History of Educational Thinking etc.

\section{References}

Aidinopoulou, V., Sampson, D.G. (2017). An Action Research Study from Implementing the Flipped Classroom Model in Primary School History Teaching and Learning. In Journal of Educational Technology \& Society, 20(1), 237247. Retrieved from http://www.jstor.org/stable/jeductechsoci.20.1.237.

Hong X., Song S. \& Jiao L. (2013). Instructional Design Based on the Idea of the Flipped Classroom in ICT Environment, Retrieved from http://en.cnki.com.cn/Article_en/CJFDTOTALJFJJ201301012.htm.

Lai, C.L., Hwang, G.J. (2016). A self-regulated flipped classroom approach to improving students' learning performance in a mathematics course. In Journal Computers \& Education, Volume 100, Pages 126-140, ISSN 0360-1315, https://doi.org/10.1016/j.compedu.2016.05.006.

Shaffer, S. (2015). One High School English Teacher: On His Way to a Flipped Classroom. Journal of Adolescent \& Adult Literacy, 59(5), 563-573. doi:10.1002/jaal.473.

Stolarczyk, E. (2009). Gra w Kolory, Program Nauczania Edukacji Wczesnoszkolnej, Wydawnictwo JUKA-91, Warszawa.

T.C. MILLÎ Eğitim Bakanlığı Talim ve Terbiye Kurulu Başkanlığı (2013). ILKOKUL've Ortaokul Görsel Sanatlar Dersi Öğretim Programı, Ankara.

Vygotski, L.S. (1972). Opere psihologice alese. București: Editura Didactică şi Pedagogică. 